\title{
Erratum to: The effect of message framing and the presentation of health vs. social consequences on health risk perception
}

\author{
F. Unger $\cdot$ M. Steul-Fischer
}

Published online: 10 September 2021

(C) The Author(s) 2021

\section{Erratum to:}

\section{ZVersWiss 2020}

https://doi.org/10.1007/s12297-020-00470-0

The article "The effect of message framing and the presentation of health vs. social consequences on health risk perception", written by F. Unger and M. Steul-Fischer, was originally published electronically on the publisher's internet portal without open access.

With the author(s)' decision to opt for Open Choice the copyright of the article changed to (C) The Author(s) 2021 and the article is forthwith distributed under a Creative Commons Attribution 4.0 International License, which permits use, sharing, adaptation, distribution and reproduction in any medium or format, as long as you give appropriate credit to the original author(s) and the source, provide a link to the Creative Commons licence, and indicate if changes were made.

The images or other third party material in this article are included in the article's Creative Commons licence, unless indicated otherwise in a credit line to the material. If material is not included in the article's Creative Commons licence and your intended use is not permitted by statutory regulation or exceeds the permitted use, you will need to obtain permission directly from the copyright holder. To view a copy of this licence, visit http://creativecommons.org/licenses/by/4.0.

The online version of the original article can be found under https://doi.org/10.1007/s12297-02000470-0

F. Unger $(\bowtie) \cdot$ M. Steul-Fischer

Lehrstuhl für BWL, insb. Versicherungsmarketing, Friedrich-Alexander-Universität

Erlangen-Nürnberg, Nürnberg, Germany

E-Mail: franziska.unger@fau.de 
Funding Open Access funding enabled and organized by Projekt DEAL.

Open Access This article is licensed under a Creative Commons Attribution 4.0 International License, which permits use, sharing, adaptation, distribution and reproduction in any medium or format, as long as you give appropriate credit to the original author(s) and the source, provide a link to the Creative Commons licence, and indicate if changes were made. The images or other third party material in this article are included in the article's Creative Commons licence, unless indicated otherwise in a credit line to the material. If material is not included in the article's Creative Commons licence and your intended use is not permitted by statutory regulation or exceeds the permitted use, you will need to obtain permission directly from the copyright holder. To view a copy of this licence, visit http://creativecommons.org/licenses/by/4. $0 /$. 